\title{
Uniformu datu bāzes struktūra
}

\author{
Iveta Ābele ${ }^{1}$, Inese Ziemele ${ }^{2}$, Ausma Vilumsone ${ }^{3}$ \\ ${ }^{1-3}$ Dizaina tehnoloğiju institūts, Materiālzinātnes un lietišşāas ķīmijas fakultāte, R̄̄ogas Tehniskā universitāte
}

\begin{abstract}
Kopsavilkums. Pētījuma mērḳis ir izstrādāt valsts iestāžu darbinieku uniformu sastāvdaļu kopkataloga konceptuālo struktūru. Kopkataloga nepieciešamību apliecina vienotas valsts garantētā apgèēba izsniegšanas, uzturēšanas un pārvaldības sistēmas trūkums. Pētījuma ietvaros izstrādāta kopkataloga datu bāzes pamatkoncepcija, entītiju relāciju diagramma un uniformu sastāvdalıu hierarhiskais datu modelis. Kopkatalogā ietverts viss uniformu sastāvdaļu dzīves cikls.
\end{abstract}

Atslēgas vārdi: Uniforma, kopkatalogs, hierarhiskais datu modelis.

\section{IEVADS}

Analizējot normatīvos dokumentus par Latvijas Republikas Iekšlietu ministrijas struktūrvienību - Valsts robežsardzes, Valsts policijas, Drošības policijas, Valsts ugunsdzēsības un glābšanas dienesta, Ieslodzījuma vietu pārvaldes un Finanšu ministrijas pārraudzībā esošā Valsts ieņēmumu dienesta muitas iestāžu (Muitas pārvaldes, Muitas policijas pārvaldes), kā arī Finanšu policijas darbinieku uniformu sastāvdal̦as, prasības apgèrbiem un to apgādes normas (1)-(6), kā arī veiktos pētījumus par iepriekš minēto struktūrvienību darba vides apdraudējumu veidiem (7) un Latvijas Valsts ieṇēmumu dienesta darbinieku apgeērba vērtējumu (8), secināts, ka darba pienākumos līdzīgu profesiju darbiniekiem no dažādām iestādēm neeksistē vienota struktūra valsts garantētā apḡērba izsniegšanai, uzturēšanai un pārvaldīšanai. Analizējot iepriekš minētos normatīvos dokumentus, secināts, ka uniformu komplekts netiek uztverts $k \bar{a}$ vienota apgēerbu slāņojuma sistēma; kā arī uz tā sastāvdal̦ām un īpaš̄īāām nav attiecinātas aizsargapgeērbiem izvirzāmās prasībās. Tādējādi netiek garantēta atbilstoša funkcionalitāte un var samazināties lietotāja veiktspēja.

Lai uzlabotu uniformu sastāvdaḷu pārskatāmību, to komplektējamību un uzskaiti, ir lietderīgi izstrādāt vienotu uniformu sastāvdalı kopkatalogu.

\section{PREČU KLASIFICĒŠANA}

Veidojot vienotu kopkatalogu, svarīgi apzināt uniformu sastāvdaļu grupēšanai saistošos Eiropas normatīvos dokumentus Latvijas Republikā. Vienotā ekonomiskās informācijas klasifikācija tiek regulēta ar Ministru kabineta 2008. gada 26. maija noteikumiem Nr.363 „Noteikumi par vienoto ekonomiskās informācijas klasifikācijas sistēmu un tās ieviešanu un lietošanas kārtību" (9).

Uz apgeērbiem attiecināms arī Lokarno nolīguma Starptautiskās klasifikācijas klašu un apakšklašu saraksts (16, 17) un Nicas klasifikācijas (NCL) 10. redakcija, kas ir spēkā no 2012. gada 1. janvāra $(18,19)$.
No 2014. gada Latvija kā NATO locekle lieto tās apgādes klasifikatoru NATO Supply Classification (NSC), (20).

Atbilstoši iepriekš minētajiem MK noteikumiem Nr.363 un to pielikumam Nr.2 „Eiropas Savienības klasifikācijas un klasifikatori”, pētījumā apskatītās uniformu sastāvdal̦as atbilst ES Kombinētās nomenklatūras (KB), (Padomes Regula (EEK) Nr. 2658/87) 61. kodu grupai ar apakšgrupām, kas tiek klasificētas kā gatavie trikotāžas geērbi un apǵērbu piederumi, 62. kodu grupai ar apakšgrupām, kas tiek klasificētas kā gēerbi un apǵērbu piederumi, kas nav no trikotāžas, 64. kodu grupai ar apakšgrupām, kas tiek klasificētas kā apavi, getras un tamlīdzīgi izstrādājumi, un 65. kodu grupai ar apakšgrupām, kas tiek klasificētas kā cepures un citas galvassegas (10).

Uz uniformu sastāvdaḷām ir attiecināms arī CPV (Common Procurement Vocabulary - kopējās publiskās iepirkumu vārdnīcas) nomenklatūras klasifikators, kas noteikts ar Komisijas Regulu (EK) Nr.213/2008/ (2007. gada 28. novembrī), (11). Iepriekš minētā regula, ar kuru veic precīzu un starptautiski saprotamu iepirkuma priekšmeta nosaukuma kodēšanu, ir noteikta vienota klasifikācijas sistēma, kas jāpiemēro publiskā iepirkuma gadījumā, lai standartizētu norādes, kuras izmanto līgumslēdzējas iestādes un līgumslēdzēji līguma priekšmeta aprakstīšanai (3).

Publiskā iepirkuma vārdnīca (CPV) ir orientēta uz produktu būtību, bet mazāk raksturo materiālu, pretstatā kombinētās nomenklatūras regulai. Uz kopkataloga apgeērbu un uniformu sastāvdal̦ām ir attiecināmas CPV kodu grupas 17000000-2 „Audumi un tekstilpreces”, 18000000-9 „Apgeērbi un apgēēba piederumi”, 19000000-6 „Āda, ādas izstrādājumi un apavi”. Tomēr, kā norāda Iepirkumu uzraudzības birojs, CPV kods nesniedz precīzu informāciju par pasūtītājam nepieciešamo iepirkuma priekšmetu vai tā tehnisko specifikāciju. Šie kodi sniedz vispārīgu norādi par iepirkuma priekšmetu, kura jāietver sludinājuma veidlapā un iepirkuma dokumentācijā (12).

KB un CPV kodi tiks izmantoti kopkataloga projektēšanā kā uniformu komplekta sastāvdaḷas raksturojošās pazīmes iepirkumu procedūru veikšanai.

\section{SISTĒMAS APRAKSTS}

Lai nodrošinātu valsts iestāžu darbinieku uniformu sastāvdal̦u iegādes un uzturēšanas izmaksu lietderīgumu un caurskatāmību, kopkatalogam jāaptver visi izstrādājuma dzīves cikla etapi, ieskaitot jauna izstrādājuma izpēti, novērtēšanu, ieviešanu, kā arī esošo un jauno izstrādājumu iegādes, ekspluatācijas un utilizācijas etapus, kvalitātes un bezatteices uzraudzību, izmantojot informāciju no atgriezeniskajām saitēm ar lietotājiem (skat. 1. attēlu). 
Jebkuram apg̣ērbam ir izvirzāmas divas prasību grupas patērētāja un ražotāja prasības.

Izstrādājot jaunas vai iepērkot esošas valsts pārvaldes iestāžu darbinieku uniformas sastāvdaļas, vienlīdz svarīgas ir abas prasību grupas. Patērētāju prasības iedalāmas sociālajās, funkcionālajās, ergonomiskajās (kurās tiek iekḷautas antropometriskās, higiēniskās un psihofiziologískās), estētiskajās, ekspluatācijas un ekonomiskajās. Ražošanas prasības iedalāmas konstruktīvi - tehnologiskajās (izstrādājuma konstrukcijas tehnologiskums, darbietilpība un model̦a izgatavošanas termin̦š) un ekonomiskajās (izgatavošanas izmaksas) (21), (22).

Pamatojoties uz iepriekš minētajām izstrādājumu prasībām, nolemts kopkataloga datu bāzes objektu aprakstošo informāciju iedalīt kvalitātes monitoringa, standartu, apdraudējumu un darba apstākḷu, lietotāju parametru, izstrādājumu parametru, izejmateriālu, palīgmateriālu parametru un izstrādājumu testēšanas pārvaldības blokos (skat. 2. attēlu).

Kopkataloga objektu īpašības plānots aprakstīt, ievadīt, uzglabāt un prezentēt skaitliskā, tekstuālā un grafiskā formā.

Kopkataloga datu bāzes modelī atlasāmi un iekḷaujami standarti un tajos nosauktās prasības, kas tiešā veidā ir attiecināmas uz konkrēto izstrādājumu vai ir pielīdzināmas vai arī pastarpināti attiecināmas. Standartu prasību neesamības gadījumā ir jāparedz iespēja izstrādāt un definēt pašiem savas izvirzāmās prasības uniformu sastāvdaļu kvalitātei. Kopkataloga datu bāzes modelī iekḷaujamas eksperimentālo modeḷu testēšanas metodes un rezultātu analīzes instrumenti.

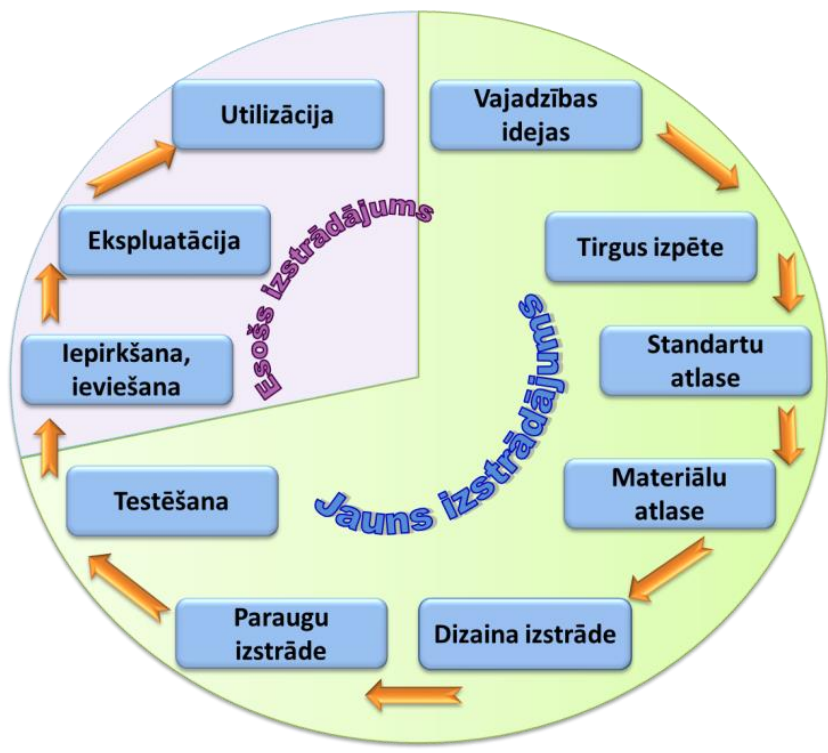

1. att. Izstrādājumu dzīves cikls.

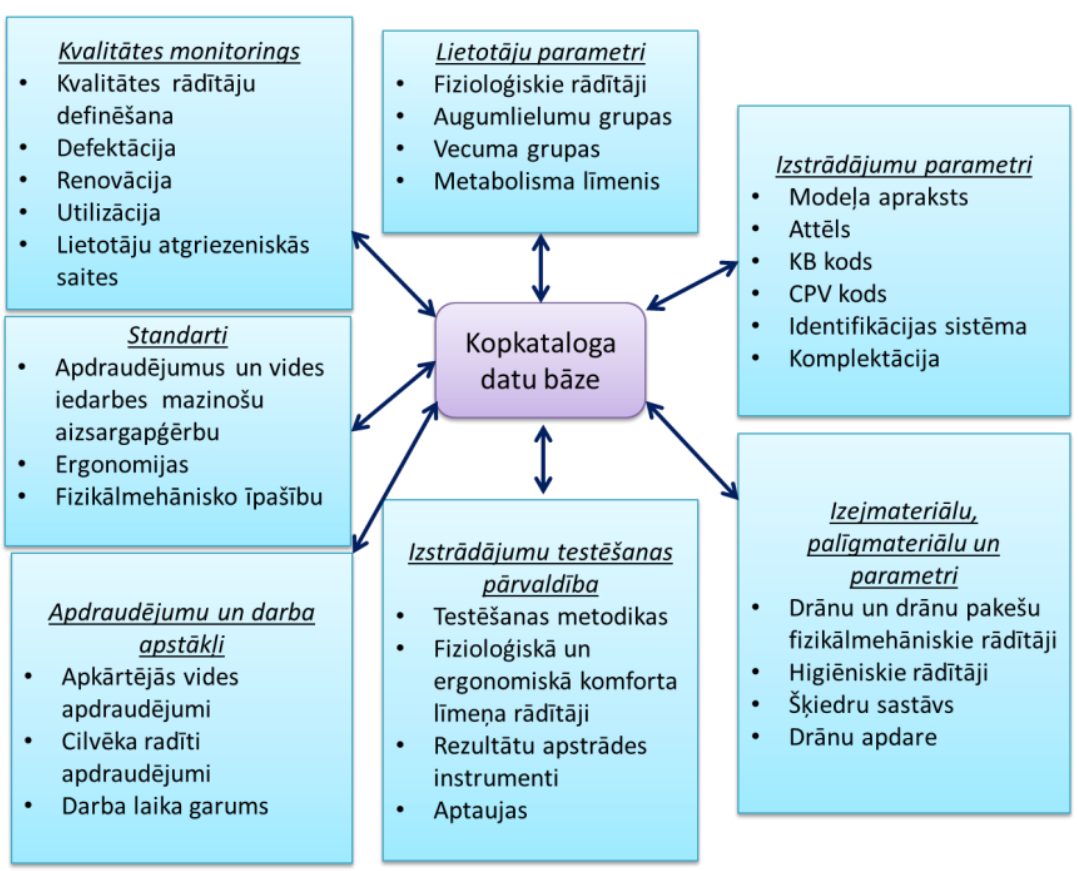

2. att. Kopkataloga datu bāzes pamatkoncepcija. 


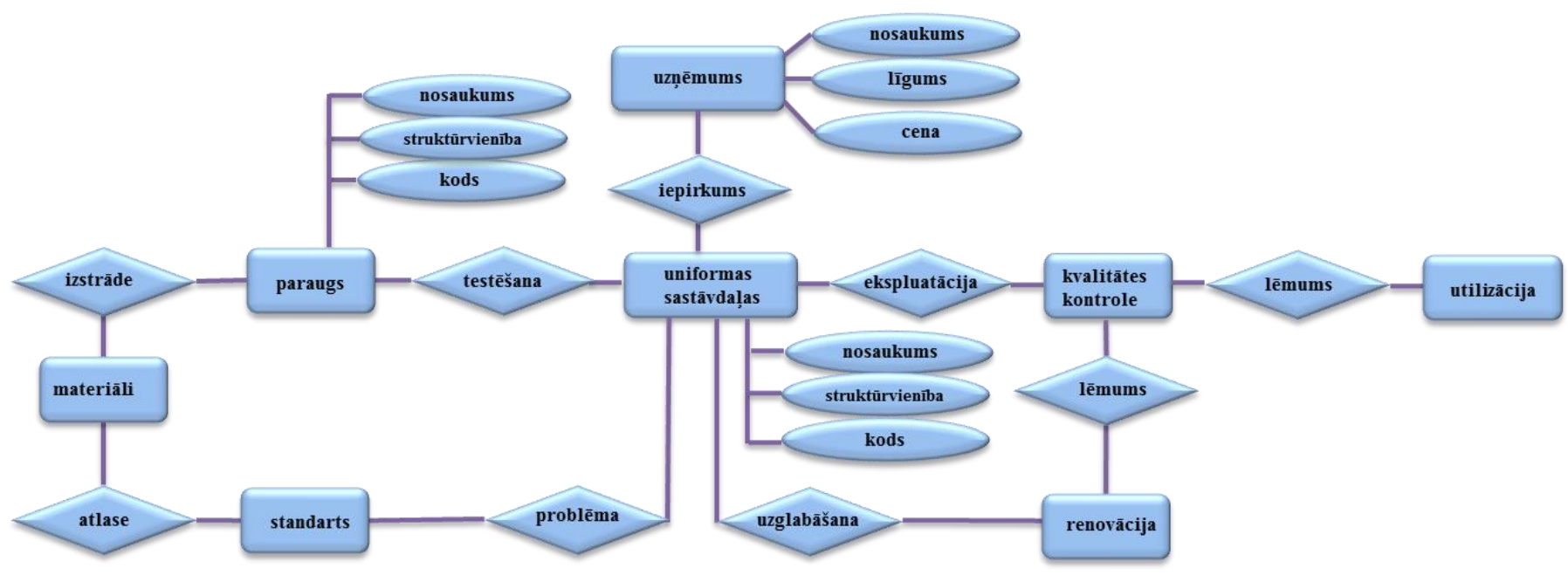

3. att. Kopkataloga entîtiju relāciju (ER) diagramma.

Darba vides apstākḷu metereologisiskā informācija, valsts struktūrvienību darbinieku antropometriskie rādītāji, uniformu komplekta siltumpretestības un tvaika caurlaidības rādītāji, kā arī darba intensitātes metobolisma līmenis lauj prognozēt cilvēka hipotermijas vai hipertermijas iestāšanos un noteikt komforta līmeni lietojot ICS (International Classification for Standards) grupas 13.180.00 ergonomikas standartus ISO 7243:1989 (23), LVS EN ISO 7730 (24), LVS EN ISO 9886 (25), LVS EN ISO 11079 (26), LVS EN ISO 15265:2004 (27).

Valsts pārvalžu darbinieku uniformas sastāvdaḷas ir ne tikai identificējamas kā atsevišķ̧i datu bāzes objekti, bet ir apskatāmas arī kā vienota apgèrbu slāņojuma sistēma. Tās funkcijas ir atkarīgas no apkārtējās vides apstākḷiem un darba specifikas faktoriem.

Valsts iestāžu uniformu ekspluatācijas laikā netiek veikts mērḳtiecīgs kvalitātes monitorings. Izstrādājot datu bāzes modeli ir nepieciešams nodrošināt informatīvo atgriezenisko saiti par defektiem un to veidiem. Kā arī sistēmā jāiekḷauj ekspluatācijas laikā konstatēto defektu informācijas analīzes instrumenti ar tām sekojošām darbībām. Sekojošās darbības var būt materiālu nomaiņa, izstrādājuma konstruktīvās izmaiṇas, tehnologiiskās izmaiṇas vai arī kardināla izstrādājumu nomaiṇa uniformu komplektā.

Izstrādājumu utilizācija ir viens no noslēguma posmiem to dz̄ives ciklā. Uniformu sastāvdaļas pieskaitāmas pie atkārtoti izmantojamiem izstrādājumiem. Utilizācijas posmā ir vairākas iespējas:

- pilnīga utilizācija, ja izstrādājums ir neatgriezeniski bojāts,

- izstrādājuma renovācija, rezervju veidošanai otrreizējai izmantošanai valsts struktūrvienības darba vajadzībām.

Uniformu sastāvdal̦u otrreizējā lietošana ārpus struktūrvienības darba jomas, ņemot vērā specifiskos darba pienākumus, nav piel̦aujama.

Kopumā datu bāzes struktūrai ir jābūt atvērtai, ar iespēju papildināt izstrādājuma aprakstošo informāciju, kā arī ar kvalitātes monitoringa elementiem.
Lai izstrādātu kopkataloga datu bāzes modeli, izveidota entītiju relāciju (ER) diagramma (skat. 3. attēlu), (13). Ar ER diagrammas palīdzību veikta uniformu sastāvdaḷu nepieciešamās informācijas atlase un to savstarpējo relāciju analīze.

\section{KOPKATALOGA OBJEKTU HIERARHISKAIS DATU MODELIS}

Pētījumā izstrādāts kopkataloga uniformu sastāvdaḷu hierarhiskais datu modelis. Tā ietvaros veikta kopkataloga objektu pazìmju atlase un klasificēšana.

Atbilstoši Eiropas Standartizācijas komitejas direktīvām uniformu komplektu sastāvdaḷu klasificēšana ir loǵiska operācija, kuras rezultātā ir iegūts uniformu sastāvdal̦u jeb objektu sadalījums savstarpēji saistītās klasēs, kuru pārstāvji savā starpā atšķiras pēc klasificētāju interesējošām pazīmēm. Klasificēšanai jābūt pilnestīgai, jānodrošina nepārklāšanās un atbilstība uzdevumam, homogēna sakārtotība, klasificējuma robežskaidrība, tai ir nepieciešams atbilstošs detalizējums un nepārprotama lietojamība (14), (15).

Uniformu komplektu sastāvdaļu kopkatalogā amatpersonu formas tērpu, speciālā apgēèrba un individuālo aizsardzības līdzekḷu sastāvdaḷas sagrupētas pēc to vienojošām pazīmēm struktūrvienība, apgèerba komplekta veids, komplekta sastāvdaļas un to îpašības. Šīs pazīmes ir pietiekošas un attiecināmas uz visām kopkataloga sastāvdal̦ām. Tālāk nosaka īpašību pakārtotību vienu otrai. Kā hierarhiskā datu modeḷa pirmā pamatpazīmju grupa, kas ir vienāda visiem izstrādājumiem, ir noteikts struktūrvienības pazīmju kopums.

Kā hierarhiskā datu modeḷa otrā specifisko pazīmju grupa, atbilstoši dažādām lietotāju grupām, ir nodalītas komplekta veida pazīmes. Kā model̦a trešā specifisko pazīmju grupa, ir nodalītas komplekta sastāvdaļu kombinējuma pazìmes. Kā model̦a ceturtā papildus informācijas grupa, ir noteiktas uniformai vai aizsargapgeērbam kopumā nepieciešamās katras sastāvdaļas īpašības. Šāda datu bāzes struktūra, iereǵistrējot tajā jaunu izstrādājumu, l̦aus to klasificēt atbilstoši formas tērpa definētajām pazīmēm (skat. 4. attēlu). 


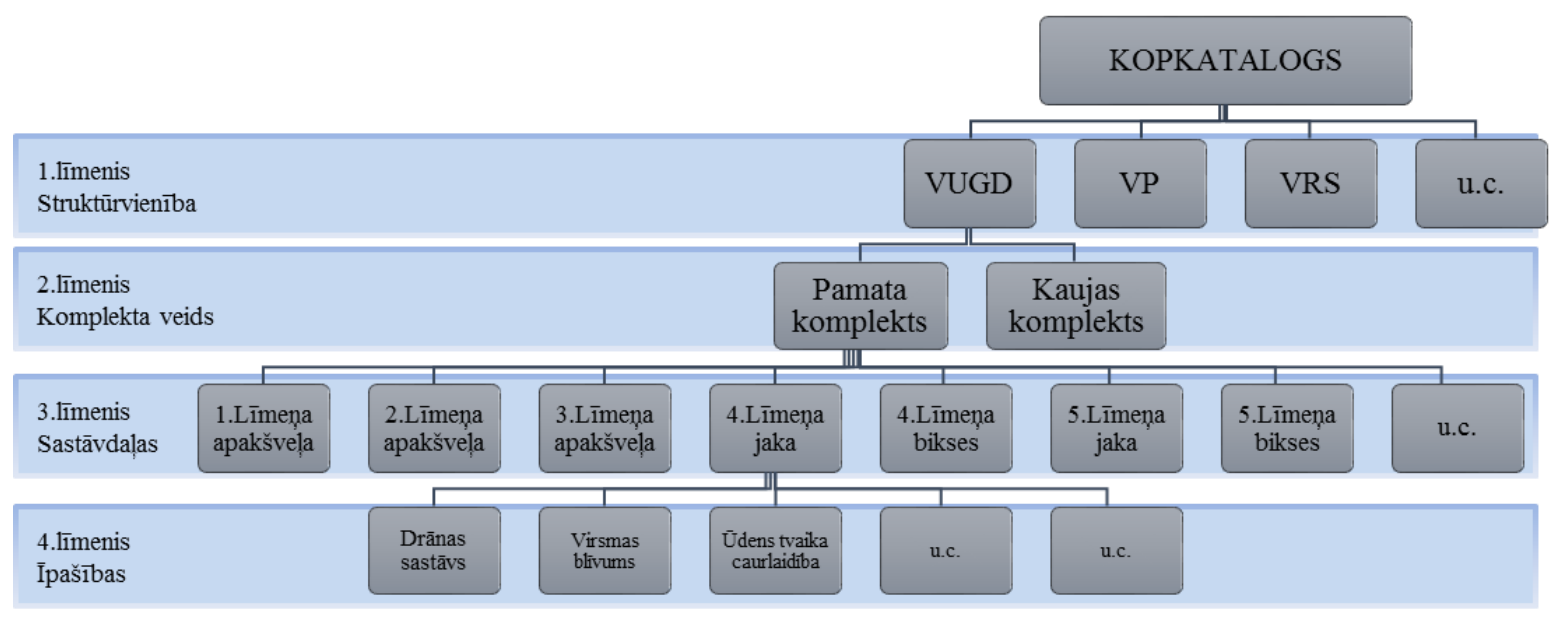

4. att. Kopkataloga uniformu sastāvdaḷu hierarhiskais datu modelis.

Trešā objektu hierarhiskā datu model̦a līmen̦a specifisko pazīmju tips sīkāk sadalīts dažādos stāṇojumos - velkamo apgèerbu septinos līmeņos (pirmā, otrā un trešā līmeņa apakšvel̦a, 4.-7. līmeņa jaka un bikses) un vasaras, ziemas un universālās (visu gadu) sezonās, kad tiek valkāta konkrēta formas tērpa sastāvdaļa (skat. 4. attēlu).

Ceturtā objektu klasificēšanas līmeņa papildus informācijas grupa sastāv no katrai formas tērpa sastāvdaļai nepieciešamo ippašỉbu kopas. Šì îpašību kopa ir apjomīga, jo apraksta izejmateriālu fizikāli mehāniskās un to lietojamības īpašības. (skat. 4. attēlu).

Izvēloties datubāzes objektu klasifikācijas pazīmes, paredzēta to iespējamā dažādība un skaita pieaugums, papildinot datu bāzi ar jauniem objektiem.

Kopkataloga informācijas masīva datubāzes struktūrā tāpat paredzēta datu meklēšanas funkcija ar meklēšanas pazīmēm, pēc kurām ir iespējams identificēt un viennozīmīgi atlasīt objektus. Izstrādājumu klasifikācijas pazīmes ir izmantotas kā pamats meklēšanas pazīmēm. Izanalizējot kopkataloga informācijas masīvu, tika nolemts pieškirt vienlīdz svarīgu nozīmi visām meklēšanas pazīmēm. Tādā veidā neierobežojot informācijas meklēšanu kopkatalogā, priekšmetu precīzai un skaidrai tehniskā apraksta izveidošanai.

\section{KOPSAVILKUMS}

Pētnieciskā darba ietvaros veikta valsts normatīvo dokumentu analīze un konstatēts vienotas uniformu sastāvdaļu izsniegšanas, uzturēšanas un pārvaldīšanas struktūras trūkums. Secināts, ka lai nodrošinātu darbinieku uniformu sastāvdaļu iegādes un uzturēšanas izmaksu lietderīgumu un caurskatāmību, kopkatalogam jāaptver visi izstrādājuma dz̄ives cikla etapi, ieskaitot jaunu izstrādājuma izpēti.

Izstrādāta datu bāzes pamatkoncepcija un noteikti tās objektu aprakstošās informācijas bloki.

Darba rezultātā izstrādāts kopkataloga uniformu sastāvdaḷu hierarhiskais datu modelis, klasificējot valsts struktūrvien̄ibu darbinieku uniformu komplektus un aizsargapgēèbu sastāvdaļas, atbilstoši veicamajiem darba pienākumiem un to veikšanai funkcionāli atbilstošu apǵērbu slān,ojumiem, drānu veidiem un to īpašībām.

Pētījuma rezultātā izstrādāts valsts iestāžu darbinieku uniformu sastāvdaļu kopkataloga teorētiskais modelis.

\section{LITERATŪRAS SARAKSTS}

1. Noteikumi par Iekšlietu ministrijas sistēmas iestāžu un Ieslodzījuma vietu pārvaldes amatpersonu ar speciālajām dienesta pakāpēm formas tērpu un atšķirības zīmju aprakstu, speciālā apgeērba, individuālo aizsardzības līdzekḷu, ekipējuma un inventāra veidiem un to izsniegšanas normām [tiešsaiste]. Ministru kabineta noteikumi Nr. 137, Rīgā 2009.gada 10.februārī (prot. Nr.11 52.§). [skatīts 30.05.2015] Pieejams: http://likumi.lv/doc.php?id=188255

2. Likums Par Valsts ieņēmumu dienestu [tiešsaiste]. Saeima 1993.gada 28.oktobrī, Rīga. [skatîts 15.04.2015] Pieejams: http://m.likumi.lv/doc.php?id=59902

3. Robežsardzes likums [tiešsaiste]. Saeima 1998.gada 1.javārī, Rīga. [skatīts 16.04.2015]Pieejams: http://m.likumi.lv/doc.php?id=46228

4. Latvijas republikas likums Par policiju [tiešsaiste]. Saeima 1991.gada 4.jūnijā, Rīga. [skatīts 16.04.2015]. Pieejams: http://m.likumi.lv/doc.php?id=67957

5. Noteikumi par Valsts ieņēmumu dienesta muitas iestāžu un finanšu policijas ierēdnuu formas tērpiem, žetonu un dienesta pakāpju atškirīibas zīmēm [tiešsaiste]. Ministru kabineta noteikumi Nr. 705, Rīgā 2013.gada 3. septembrī (prot. Nr. 47 45.§). [skatīts 20.05.2015] Pieejams: http://m.likumi.lv/doc.php?id=259555

6. Valsts ugunsdzēsības un glābšanas dienesta nolikums [tiešsaiste]. Ministru kabineta noteikumi Nr.398, Rīgā 2010.gada 27. aprīlī (prot. Nr. 21 7.§). [skatīts 20.05.2015] Piejams: http://m.likumi.lv/doc.php?id=209089

7. Ābele, I., Vilumsone, A., Strazds, G. Evaluation of Uniforms for Administrative Institutions of the Ministry of the Interior of the Republic of Latvia. Scientific Journal of Riga Technical University: vol. 6, 2011. p. 92-98. ISSN 1691-3132.

8. Šroma, I., Ziemele, I., Rudzika, S. Latvian State Revenue Service employees clothing self - assessment in the survey. Material Science. Textile and Clothing Technology. Vol. 9, 2014, p.1-10. Available from: https://files.rtu.lv/zdas/publications/19312/pub19312.docx

9. Noteikumi par vienoto ekonomiskās informācijas klasifikācijas sistēmu un tās ieviešanas un lietošanas kārtību [tiešsaiste]. Ministru kabineta noteikumi Nr..363, Rīgā 2008.gada 26.maijā. [skatīts 02.06.2015] Pieejams: http://likumi.lv/doc.php?id=175979

10. Commission Implementing Regulation (EU) No 1101/2014 of 16 October 2014 amending Annex I to Council Regulation (EEC) No 2658/87 on the tariff and statistical nomenclature and on the Common Customs Tariff [online]. [viewed 11 May 2015]. Available from: https://eparskats.csb.gov.lv/HelpDesk/UI/Page.aspx?pid=452 
11. Komisijas regula (EK) Nr. 213/2008 [tiešsaiste], [skatīts 10.01.2015]. Pieejams: content/LV/TXT/?uri=CELEX:32008R0213

12. Iepirkumu uzraudzības birojs. Klasifikācija. Kopējā iepirkuma vārdnīca (Common Procurement Vocabulary - CPV) jeb CPV nomenklatūras klasifikators . Pieejams: http://212.70.190.82/node/77

13. Bagui, S., Earp, R. Database Design Using Entity-Relationship Diagrams. 2 ed. (Foundations of Database Design), CRC Press, Auerbach Publications, September 7, 2011, p. 371, ISBN 9781439861769

14. CWA 15295:2005. Description of References and Data Models for Classification. Brussels: CEN, August 2005. 130 p.

15. CWA 15294:2005. Dictionary of Terminology for Product Classification and Description. Brussels: CEN, May 2005. 26 p.

16. International Classification of Industrial Designs, 10th Edition. [Online] Available from: http://www1.fips.ru/wps/portal/IPC/MKPO10_HTML/

17. Locarno Classification of Industrial Designs, 10th ed. on Jan. 1, 2014, [Online] Available from: http://www.wipo.int/classifications/locarno/en/

18. Titles of Classes of Goods and Services, according to the Nice Classification, 10th Edition on January 1, 2012. [Online] Available from:http://www.lrpv.gov.lv/lv/precu-zimes/nicas-klasifikacija/klasuvirsraksti

19. Nice Classification. [Online] Available from: http://www.wipo.int/classifications/nice/en/

20. NATO Supply Classification. [Online] Available from: https://wikileaks.org/wiki/Federal_Supply_Group

21. Apurba, D and Alagirusamy, R. Science in Clothing Comfort. Woodhead Publishing India Pvt. Ltd, 2010, pp.175. ISBN 13: 978-81-908001-5-0

22. Saveljeva I, N. Hudozjestvennoje projektorovanije specodedzi dlja rabocih gorjacih cehov. Legkaja promislennostj i bitovoje obsluzivanije: Moskva, 1988, s. 208. ISBN 5-7088-0217-0

23. ISO 7243:1989 Hot environments Estimation of the heat stress on working man, based on the WBGT-index (wet bulb globe temperature)

24. LVS EN ISO 7730:2006 Siltuma vides ergonomika. Termālā komforta analītiska noteikšana un interpretācija, izmantojot paredzamā vidējā balsojuma (PMV) un paredzamā neapmierināto personu procenta (PPD) indeksu kalkulāciju un lokālā termālā komforta kritêrijus

25. LVS EN ISO 9886:2004 Termiskās spriedzes novērtējums ar fiziolog̣iskajiem mērījumiem

26. LVS EN ISO 11079:2008 Siltumvides ergonomika. Aukstuma stresa noteikšana un interpretācija izmantojot aizsargapǵērba siltumizolāciju un lokālos atdzesēšanas efektus

27. LVS EN ISO 15265:2004 Aukstas un karstas vides ergonomika Apdraudētības noteikšanas stratēgija stresa vai sliktas pašsajūtas profilaksei aukstos un karstos darba apstākḷos.

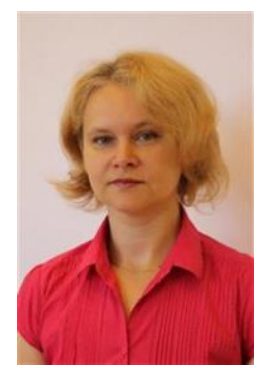

Iveta Abele received $M g$. sc. ing. degree in Clothing and Textile Technology and the Qualification of Engineer in Clothing and Textile Production in 1998 at Riga Technical University.

She is currently a Doctoral student at Riga Technical University. She is a supervisor of studies (since 2013) and a researcher (since 2010) at the Institute of Design Technologies, Faculty of Materials Science and Applied Chemistry, Riga Technical University.

Her current research topic is functional clothing.

Address: Institute of Design Technologies, Riga Technical University, Kipsalas Str. 6, Riga, LV-1048, Latvia.

E-mail: iveta.abele@rtu.lv

Phone: + 37129385283

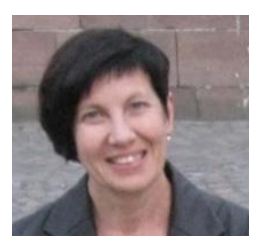

Inese Ziemele holds the title Dr. sc. ing. Her research topic was optimization of sewing parameters and selective methods of sewing machines to assure guaranteed quality in the garment production.

From 1998 to 2007 she was a senior tehnologist at LLC Solutions, Riga, Latvia; and since 2007 she is a researcher and an Assistant Professor at Institute of Design Technologies, Faculty of Materials Science and Applied Chemistry, Riga Technical University.

Her research interests are: apparel production technologies, design of production processes in sewing companies, apparel logistic.

Address: Institute of Design Technologies, Riga Technical University, Kipsalas Str. 6, Riga, LV-1048, Latvia.

E-mail: inese.ziemele@rtu.lv

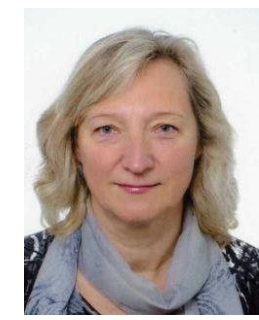

AusmaVilumsone, Dr. sc. ing. is a Professor at the Institute of Design Technologies, Riga Technical University. She is the Head of the Department of Clothing and Textile Technologies. Her scientific interests are: development and optimization of technological process of garment design, CAD/CAM systems in product design, innovative materials and technologies.

Address: Institute of Design Technologies, Riga Technical University, Kipsalass str. 6, Riga, LV-1048, Latvia.

E-mail: ausma.vilumsone@rtu.lv

\section{Iveta Abele, Inese Ziemele, Ausma Vilumsone. Structure of a Uniform Database}

In this research normative documents of institutions supervised by the Ministry of Interior (MI) - State Border Guard (SBG), State Police (SP), Security Police (SP), State Fire and Rescue Service (SFRS), Prison Administration (PA), Customs institutions (Customs Administration, Customs Police Administration) of State Revenue Service (SRS) were analysed and it was recognized that there is a structure deficiency in dispensation, maintenance and management of united components of uniforms. It was also concluded that the uniform set is not perceived as a united system of fabric layers of clothing. Uniform components and their properties are not extended to requirements for protective clothing. This does not guarantee the right functionality and may reduce the performance of users. The government institution has been useful to develop unified database for uniform components, supply and accounting.

To improve appropriate supply of uniform components and costs of maintenance, the information in the database should include all phases of the life cycle of the product. The aim of this paper is to develop a conceptual structure for database of uniform components of national enforcement employees.

In this study has been designed the basic concept of a database and identified blocks of descriptive information. The global catalogue has been included all phases of uniform component life cycle. To develop a global catalogue database model an entity relationship (ER) diagram was established. The necessary information for selection of the components of the uniform components was produced using the ER diagram and their mutual relationship was analysed.

During research hierarchical data model of the given components of a uniform was generated and a classification of government employee uniforms and of protective components was carried out in accordance to duties and performance of functionally appropriate system of layers of clothes, cloth types and their properties. Choosing classification signs of objects from a database has provided their increase and variety at addition with new subject.

As a result of this research the theoretical model of database of government institution employee uniform components has been developed. 
Ивета Абеле, Инесе Зиемеле, Аусма Вилюмсоне. Структура базы данных униформ.

Проведенный анализ государственных нормативных документов структурных подразделений министерства Внутренних дел Латвии Государственной полиции, Полиция безопасности, Государственной пограничной службы, Государственной пожарно-спасательной службы показал отсутствие единой системы выдачи, поддержания, определения общей структуры составляющих униформы. Так же выяснено, что комплект униформы не воспринимается как единая система слоев одежды. На составляющие униформы и их свойства не распространяются требования защитной одежды. В этом случае невозможно гарантировать соответствующую функциональность, и в результате может снизиться трудоспособность пользователя. Чтобы улучшить наглядность, комплектование и учёт составляющих униформы целесообразно разработать базу данных. Так же установлено, что в базе данных необходимо объединить все этапы цикла использования составляющих униформы, разработки новых изделий. Таким образом, обеспечивается целесообразность контроля при закупке и содержании составляющих униформы. Цель данного исследования - разработать концептуальную структуру базы данных для работников государственных учреждений.

В рамках исследования разработана основная концепция базы данных и определены блоки описательной информации. В общем каталоге прослеживаются все этапы цикла использования составляющих униформы. Чтобы разработать модель общего каталога базы данных, была создана диаграмма соотношения логических объектов. С помощью диаграммы был произведён отбор основной информации и анализ соотношения логических объектов. В процессе исследования создана иерархическая модель данных составляющих униформы. Также произведена классификация комплектов униформы и защитной одежды работников государственных учреждений с учетом их служебных обязанностей, системы слоев одежды, видов полотна и их свойств.

При выборе классификационных признаков объектов базы данных предусмотрено их увеличение и многообразие при дополнении новыми предметами.

В результате исследования разработана теоретическая модель базы данных. 